\title{
CASE NOTE: QUESTIONS RELATING TO THE SEIZURE AND DETENTION OF CERTAIN DOCUMENTS AND DATA
}

\author{
Massimo Fabio Lando ${ }^{*}$
}

\section{Introduction}

The International Court of Justice issued its first decision of 2014 following a request for provisional measures filed by the Democratic Republic of Timor-Leste in a dispute against the Commonwealth of Australia on the seizure and detention of certain documents and data. ${ }^{1}$ The facts of the case are curious, but the legal questions are certainly not less worthy of attention. The order on provisional measures of 3 March 2014 is a good example of legal consistency and jurisprudential coherence, even if the Court could have gone further by granting, on the basis of the same reasoning, the provisional measures sought by Timor-Leste.

\section{The Facts of the Case}

The dispute before the ICJ arose in the broader context of the Timor Sea Treaty arbitration, initiated on 23 April 2013 by Timor-Leste pursuant to Article 23 of the Timor Sea Treaty, ${ }^{2}$ concluded in 2002 and regulating the regime of exploitation of the natural resources in the Timor Sea. Timor-Leste instituted arbitral proceedings requesting that the 2002 Treaty be declared void on the grounds that Australia had bugged Timor-Leste's Cabinet room during the negotiations. The arbitral tribunal will hear the oral arguments in September 2014.

The ICJ dispute concerns, as the name of the case indicates, the seizure and detention by Australia of certain documents and data allegedly belonging to Timor-Leste and relating to the Timor Sea Treaty arbitration. The seizure

\footnotetext{
St Catharine's College, University of Cambridge.

1 Questions relating to the Seizure and Detention of Certain Documents and Data (Timor-Leste $v$ Australia), ICJ, Provisional Measures, Order of 3 March 2014 (Certain Documents and Data).

2 Timor Sea Treaty, 20 May 2002, 2258 UNTS 3.
}

Copyright $\odot$ the Author(s).

This work is licensed under a Creative Commons Attribution-NonCommercial-NoDerivs 3.0 License. 
of such documents was conducted pursuant to a warrant issued under s 25 of the Australian Security Intelligence Organisation Act 1979 (Cth), and occurred on the premises of 5 Brockman Street, Narrabundah, in the Australian Capital Territory, on 3 December 2013. ${ }^{3}$ The documents removed and detained by the Australian authorities were under the custody of Mr Bernard Collaery, one of Timor-Leste's legal advisers in the Timor Sea Treaty arbitration.

Timor-Leste claimed that Australia had breached its sovereign rights over the property seized, entitled to immunity as state property. It also contended that Australia had violated Timor-Leste's right to confidentiality in the communications between itself and its legal counsels, maintaining that legal professional privilege is a general principle of law. ${ }^{4}$ In particular, Timor-Leste's concern was that Australia could avail itself of the information contained in the seized documents in relation to the Timor Sea Treaty arbitration. ${ }^{5}$

For its part, Australia argued that Timor-Leste's property over the documents seized is yet to be proved. Even if the property were proved, Australia contends that there is no general principle of inviolability of state papers and property, and, accordingly, Timor-Leste's claimed rights are not plausible. Furthermore, were a principle of inviolability of state documents be found to exist, Australia contended that it could not be absolute, as it cannot apply where the matter to which the documents relate concerns national security. ${ }^{6}$

Before the delivery of the order on provisional measures, the ICJ had been requested by Australia to stay the proceedings initiated by Timor-Leste until the settlement of the Timor Sea Treaty arbitration. In its order of 28 January 2014, the Court did not accede to such request, ${ }^{7}$ since the application of Timor-Leste to the ICJ concerned a subject-matter sufficiently distinct from that of the Timor Sea Treaty arbitration. ${ }^{8}$

3 Certain Documents and Data, above $\mathrm{n} 1$, para 1.

4 Ibid, para 24.

5 Certain Documents and Data, Timor-Leste: Request for Provisional Measures, 17 December 2013, para 6.

6 Certain Documents and Data, above n 1, para. 25.

7 Questions relating to the Seizure and Detention of Certain Documents and Data (Timor Leste $v$. Australia), Order of 28 January 2014.

8 Certain Documents and Data, above n 1, para 17. 


\section{The Order of 3 March 2014}

In its decision on Timor-Leste's request for provisional measures, the Court analysed in turn the requirements for the indication of provisional measures under Article 41 of its Statute: prima facie jurisdiction, plausibility of the rights claimed and link between such rights and the mainline proceedings, risk of irreparable prejudice, and urgency. ${ }^{9}$

The Court began by analysing the least controversial requirement, prima facie jurisdiction. In its application, Timor-Leste founded the Court's jurisdiction on '[...] the declaration it made [...] under Article 36, paragraph 2, of the Statute, and on the declaration Australia made [...] under the same provision [...].10 The Court concluded that those grounds appeared to afford a basis on which jurisdiction could be asserted. ${ }^{11}$ The question was easily settled also due to Australia not raising any objections to jurisdiction, reserving its arguments on the matter for the subsequent phases of the case. ${ }^{12}$

The Court subsequently turned to the question of the rights claimed by Timor-Leste. Provisional measures can be indicated only if the rights claimed by the applicant on the merits are plausible, and if there is a connection between those rights and the provisional measures sought. ${ }^{13}$

The rights claimed by Timor-Leste were the inviolability and immunity of its property pursuant to the principle of sovereignty, and the confidentiality it is entitled in the communications with its legal advisers under a general principle of law. Australia rejected Timor-Leste's contentions. The parties did not dispute that at least part of the documents related to the Timor Sea Treaty arbitration, and the Court noted that the right to immunity and inviolability of property invoked by Timor-Leste did appear to flow from the general principle of sovereign equality of States, enshrined in Article 2(1) of the Charter of the United Nations. ${ }^{14}$ The ICJ also added that sovereignty must be respected when the States concerned are in the process of peacefully settling a dispute, such as in the case of the Timor Sea Treaty arbitration, in accordance with Article 2(3) UN Charter. ${ }^{15}$ The Court

\footnotetext{
9 K Oellers-Frahm, 'Article 41', in A Zimmermann et al (eds), The Statute of the International Court of Justice: A Commentary (2nd edn, 2012) 1026, 1038.

${ }^{10}$ Certain Documents and Data, above n 1, para 19.

${ }^{11}$ Ibid, para 21.

${ }^{12}$ Ibid, para 20.

${ }^{13}$ Ibid, paras 22-3.

${ }^{14}$ Under Art 2(1) of the UN Charter ' $t$ ] he Organization is based on the principle of the sovereign equality of all its Members'.

${ }^{15}$ Under Art 2(3) of the UN Charter '[a]11 Members shall settle their international disputes by
} 
thus found that the rights invoked by Timor-Leste were plausible.

As to the link between the rights claimed and the provisional measures requested, in light of the purpose of the measures sought by Timor-Leste, namely to prevent further access by Australia to the documents and interference in the communications between Timor-Leste and its legal advisers, the Court held that the provisional measure requested were '[...] by their nature [...] intended to protect Timor-Leste's claimed rights [...]'. ${ }^{\prime 6}$ Therefore, the provisional measures requested were linked to the rights claimed.

The Court analysed in turn what proved to be the most controversial issue of the provisional measures phase, the risk of irreparable prejudice to the rights claimed and the urgency of the situation.

Irreparable prejudice was examined by the Court in light of the unilateral commitments made by Australia on 21 January 2014, by which it undertook not to divulge the content of the documents seized on 3 December 2013, as well as not to avail itself of the information contained therein for any purpose relating to the Timor Sea Treaty arbitration. Australia maintained that the undertaking, presented to the ICJ by its Attorney-General, Senator George Brandis, was enough to dispel any doubt as to the protection of Timor-Leste's rights pending the dispute. Timor-Leste, for its part, contended that the Australian undertaking was not sufficient to preserve its rights, and that it certainly did not remove the urgency of the request for provisional measures. ${ }^{17}$

The Court held that if Australia '[...] failed to immediately safeguard the confidentiality of the material seized', the '[...] right of Timor-Leste [...] could suffer irreparable harm,', ${ }^{18}$ and that '[a]ny breach of confidentiality may not be capable of remedy or reparation as it might not be possible to revert to the status quo ante following disclosure of the confidential information.' ${ }^{19}$ The ICJ analysed the Australian undertaking, and affirmed that '[...] the Court has no reason to believe that the written undertaking [...] will not be implemented by Australia, ${ }^{20}$ Nevertheless, the undertaking alone was not deemed enough to safeguard Timor-Leste's rights, as it presented a significant carve-out under which the documents could be used by the Australian government for national

peaceful means in such a manner that international peace and security, and justice, are not endangered'.

${ }^{16}$ Certain Documents and Data, above n 1, para 30.

17 Ibid, para 41.

18 Ibid, para 42.

19 Ibid.

${ }^{20}$ Ibid, para 44. 
security purposes. In light of this, the Court found that there remained a risk of disclosure, which led to the conclusion that despite the undertaking making '[...] a significant contribution towards mitigating the imminent risk of irreparable prejudice [...], ${ }^{21}$ it did not remove that risk entirely. The Court thus concluded that the requirement of irreparable prejudice was met. ${ }^{22}$

The Court went on to the final part of the order by considering the measures appropriate in the circumstances. Exercising its power under Article 75(2) of its Rules, the ICJ indicated measures different in part from those requested, namely that the seized materials must be kept '[...] under seal until further decision of the Court. ${ }^{23}$ In addition, the Court indicated a provisional measure to the end that Australia must not interfere with any communication between Timor-Leste and its legal advisers with regard to the Timor Sea Treaty arbitration, the ICJ proceedings to which provisional measures are incidental, and any future bilateral negotiation concerning maritime delimitation between the two countries. $^{24}$

\section{Comment}

The Court seems to have issued a balanced order, which does not accede completely to Timor-Leste's request, and which arguably pursues the aim of avoiding the exacerbation of the dispute. However, if certain points of the Court's analysis, such as prima facie jurisdiction, are unassailable, the plausibility of the rights invoked by Timor-Leste and irreparable prejudice appear more controversial. The disagreement over these issues within the Court itself is apparent in light of the not negligible number of dissents (Judges Keith and Greenwood, Judge ad hoc Callinan) and of separate opinions (Judges Cançado Trindade and Donoghue).

The issue of the plausibility of the rights invoked by Timor-Leste was addressed by Judge ad hoc Callinan's dissent, which stated that '[t]he existence of a sovereign inviolability of documents in the possession of a lawyer in another country is a large claim and [...] possibly novel. ${ }^{25}$ Judge ad hoc Callinan's point is sound, and an answer to the questions can only be reached after the oral arguments on the merits have been heard. However, the Court appears to have

\footnotetext{
${ }^{21}$ Ibid, para 47.

22 Ibid, para 48.

${ }^{23}$ Ibid, para 51.

${ }^{24}$ Ibid, para 52.

${ }^{25}$ Ibid, para 25 (Judge ad hoc Callinan, diss.
} 
treated the question of the plausibility of the rights correctly, as it recognised that at provisional measures stage it is not called upon to decide definitively on the matter, having to make a mere provisional finding on the existence of such rights. ${ }^{26}$ A parallel can be drawn between the questions of jurisdiction and of the existence of rights claimed by the applicant, as in both cases the Court is only required to make prima facie decision, which in no way prejudges the more accurate analysis conducted later in the proceedings.

The most controversial part of the order of the Court concerned the Australian undertaking. Given the Court's previous jurisprudence, ${ }^{27}$ both parties probably expected that the Court would deliver an order accepting Australia's undertaking, with the outcome being either the decline to indicate provisional measures, or the indication of a provisional measure indicating that Australia must comply with the terms of its very undertaking. The decision of the Court arguably took both parties by surprise, and certainly Australia.

The undertaking was made by the Australian Attorney-General, who had the power to bind his country as a matter of both Australian and international law. ${ }^{28}$ The Court appeared satisfied with such undertaking, expressing its conviction that it would be respected, ${ }^{29}$ yet it indicated provisional measures nonetheless.

The decision of the Court was criticised in two different ways in the opinions appended to the order. On one hand, Judges Keith, Greenwood, Donoghue, and Judge ad hoc Callinan, criticised the limited reliance of the Court on the Australian undertaking, which, in their view, dispelled any risk of irreparable prejudice, with the consequence that provisional measures should not have been indicated. On the other hand, Judge Cançado Trindade criticised the decision

${ }^{26}$ Ibid, para 26. See also P Tomka \& G Hernández, 'Provisional Measures in the International Tribunal for the Law of the Sea', in H Hestermeyer et al (eds), Coexistence, Cooperation and Solidarity: Liber Amicorum Rüdiger Wolfrum (2012) 1764.

${ }^{27}$ The Court has relied on unilateral undertakings in other previous cases. See, for instance, Legal Status of the South-Eastern Territory of Greenland (Norway v Denmark) (1932) PCIJ Series A/B No 48, 21ff, where the PCIJ denied the Norwegian request for provisional measures in light of the reciprocal undertakings of Denmark and Norway. ITLOS also relied on unilateral undertakings, most notably in the Case concerning Land Reclamation by Singapore in and around the Straits of Johor (Malaysia $v$ Singapore), Provisional Measures (2003) 126 ILR 503, where the Tribunal prescribed, as provisional measures, that the undertakings by Singapore should have been respected. In Nuclear Tests (Australia v France), ICJ Reports 1974 p 253, 260 ff., the question was that of mootness of the dispute due to the French undertaking not to carry out further nuclear experiments in the Pacific; however, such a question was dealt with in the merits, and not at provisional measures stage.

${ }^{28}$ Certain Documents and Data, above n 1, para 44.

29 Ibid. 
on the grounds that any degree of reliance on the Australian undertaking would have been a mistake. ${ }^{30}$ For her part, Judge Donoghue distinguished between the provisional measures indicated by the Court. While on one hand she disagreed with operative paragraphs 1 and 2, stating that they were covered by the Australian undertaking, she voted in favour of operative paragraph 3 , as the question of the communication between Timor-Leste and its legal advisers was not addressed by the undertaking. ${ }^{31}$

Notwithstanding the criticism directed towards the Court's order, it appears that the Court reached the most appropriate decision. In support of their contention that provisional measures should not have been indicated due to the undertaking binding Australia as a matter of international law, the dissenting judges cited the order on provisional measures issued in Obligation to Prosecute or Extradite, where the Court refused to exercise its powers under Article 41 of the Statute since Senegal had assured that it would not allow former President of Chad Hissène Habré to leave the country pending ICJ proceedings. ${ }^{32}$ However, the reliance on that case is misplaced, as there exists a fundamental difference between the Senegalese and the Australian undertaking. While the Senegalese undertaking was absolute in character, entailing that Hissène Habré would not be allowed to leave the country under any circumstances, ${ }^{33}$ the Australian undertaking provided for a substantial carve-out allowing Australia to use the information in the seized documents for purposes of national security. The Court correctly saw in this saving clause the possibility that Timor-Leste could in fact suffer irreparable prejudice to its rights pending the judgment, also in view of the flexible character of the national security exception. In the author's view the Court acted consistently with its jurisprudence, as the two cases are different, and thus do not require the same solution.

At the other end of the spectrum, the opinion of Judge Cançado Trindade displays his typical attitude of furthering the progressive development of international law through the exercise of the Court's judicial function. In a flamboyantly drafted opinion, Judge Cançado Trindade questions the Court's reliance on unilateral undertakings, arguing that ex factis jus non oritur, and that the Court should stop acting as a diplomatic amiable compositeur and take up behaving as

\footnotetext{
${ }^{30}$ Ibid, paras 13ff (Judge Cançado Trindade).

31 Ibid, para 5 (Judge Donoghue).

32 Questions relating to the Obligation to Prosecute or Extradite (Belgium v Senegal), Provisional Measures, ICJ Reports 2009 p 139, 154.

33 Ibid.
} 
a court of law. ${ }^{34}$ As it sometimes occurs, Judge Cançado Trindade's view appears to be ahead of its time and is certainly interesting, but it would contradict long-standing state practice, which has consistently placed reliance on unilateral undertakings. ${ }^{35}$ Moreover, Judge Cançado Trindade's idea that provisional measures are autonomous in the context of international procedure contradicts the quasi-unanimous opinion that provisional measures are an incidental feature of the proceedings. ${ }^{36}$ Contrary to what he states, the rights claimed by the parties on the merits are exactly those requiring protection at provisional measures stage. If the contrary were true, the very nature of provisional protection would be jeopardised, since provisional measures can only be granted if connected to the rights claimed on the merits. ${ }^{37}$ In addition, the undisputed fact that the obligations of compliance flowing from an order on provisional measures and from a judgment are different, does not entail that provisional measures are autonomous. The fact that provisional protection is incidental to the mainline proceedings is confirmed by the fact that orders on provisional measures usually lapse with the delivery of the final judgment. ${ }^{38}$

The Court did not directly mention urgency in its order, seemingly basing its analysis on irreparable prejudice. However, a close reading of the order shows that urgency was well in the judges' minds, as demonstrated by the reference to the 'imminent risk of irreparable prejudice.' ${ }^{39}$ Imminence of the prejudice is but a different manner to refer to urgency.

As a final aspect, one must note that in operative paragraph 3, the Court indicated, as provisional measures, that Australia '[...] shall not interfere in any way in communications between Timor-Leste and its legal advisers' in connection with matters concerning the Timor Sea Treaty arbitration, with future negotiations between the parties on maritime delimitation, or with the pending case before the ICJ. Timor-Leste had not specifically requested such a provisional measure, and little evidence was presented to the Court on the question. However, this decision was attended by very little dissent: only Judge ad

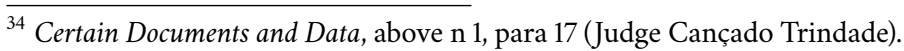

${ }^{35}$ C Goodman, Acta Sunt Servanda: A Regime for Regulating the Unilateral Acts of States at International Law (2006) 25 Australian YIL 43.

${ }^{36}$ Sh Rosenne, Provisional Measures in International Law: the International Court of Justice and the International Tribunal for the Law of the Sea (2005) 9; G Fitzmaurice, The Law and Practice of the International Court of Justice, vol 2 (1986) 533.

${ }^{37}$ L Collins, Provisional and Protective Measures in International Litigation (1992) 234 Hague Recueil 232.

${ }^{38}$ J Sztucki, Interim Measures in the Hague Court: An Attempt at a Scrutiny (1983) 198.

${ }^{39}$ Certain Documents and Data, above n 1, paras 32, 48. 
hoc Callinan incidentally raised the point, ${ }^{40}$ while even Judge Donoghue, critical of the Court's order, declared herself in agreement with operative paragraph $3 .^{41}$

\section{Conclusion}

The Court could have dared to grant the measures requested by Timor-Leste and demand that Australia deliver the sealed documents at the Peace Palace, as in this manner the risk of irreparable prejudice could be avoided more efficiently. However, this does not change the fact that the Court's reasoning is an example of consistency and coherence with the Court's previous jurisprudence. The decision to grant the measures requested by Timor-Leste in full would not, in the author's opinion, have changed the reasoning of the Court. The only change would have been the manner in which the Court exercised it discretion as to the provisional measures to indicate under Article 41 of the Statute.

\footnotetext{
${ }^{40}$ Ibid, paras 27, 32 (Judge ad hoc Callinan, diss).

${ }^{41}$ Ibid, para 5 (Judge Donoghue).
} 